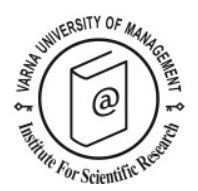

\title{
Diagnosing customers experience, emotions and satisfaction in Malaysian resort hotels
}

\author{
Faizan Ali ${ }^{1 *}$, Kashif Hussain ${ }^{2}$ and Rosmini Omar ${ }^{3}$
}

Received: 31/05/2014 Accepted: 05/07/2015

\footnotetext{
1 Post-Doctoral Scholar, International Centre for Hospitality Research, Dedman School of Hospitality, Florida State University, 288 Champions Way, B2200 University Center, P.O. Box 3062541, Tallahassee, FL 323062541, phone: +1-850-459-2545, e-mail: faizanali7@hotmail.co.uk

${ }^{2}$ Associate Professor, Faculty of Hospitality and Tourism Management, UCSI University, 56000 Kuala Lumpur, Malaysia, e-mail: kashif.hussain@msn.com

3 Associate Professor, International Business School, Universiti Teknologi Malaysia, International Campus, 54100, Kuala Lumpur, Malaysia, e-mail: rosmini@ibs.utm.my

* Corresponding author
}

\begin{abstract}
Despite the increasing attention towards customer experience, empirical research to explain this notion and its consequences is still limited. Hence, this study aims to examine the effect of customer's experience with four dimensions on their emotions and satisfaction. A convenience sampling technique was used to select a sample of 600 at two tourist spots of Malaysia i.e., Langkawi and Penang. 450 questionnaires were returned back and the data was analysed using partial least square based structural equation modelling. Findings reveal that all the four dimensions of customer experience influence customer emotions which develop customer satisfaction. Resort hotels are least focused facet of tourism industry; therefore, this study validates the customer experience scale in the context of resort hotels and enhances the theoretical progress on the experience concept in relation with customer emotions and satisfaction and offer important implications for resort hotel marketers.
\end{abstract}

(C) 2016 Varna University of Management. All rights reserved

Keywords: Customer Experience, Emotions, Customer Satisfaction, Resort Hotels, Partial Least Squares.

Citation: Ali F., K. Hussain and R. Omar (2016) Diagnosing customers experience, emotions and satisfaction in Malaysian resort hotels. European Journal of Tourism Research 12, pp. 25-40

\section{Introduction}

Resort hotels are becoming one of the fastest growing segments of tourism attractions around the world. Since economic boom from 1960s, resort hotels are gaining gradual popularity and the service providers are facing challenges to satisfy the needs and wants of the tourists visiting these facilities (Ali et al., 2013). In the recent decade, a drastic increase is observed in the number of tourists travelling to resort hotels situated in the natural exotic locations to escape from their daily routine life and to enjoy 
and entertain themselves. Yang and Chan (2010) states that studying resort hotels are important as it can help the establishments to design better products and services to satisfy the customers, understand their decisionmaking process and emotions.

The rapid development in this tourism sector makes it very competitive and enforces the resort hotels to develop various marketing strategies for ensuring customer satisfaction (Geissler and Rucks, 2011; Wu and Liang, 2009). Contextually, Gee (2000, p.22) stated that, 'the core principle of the resort concept is the creation of an environment that will promote and enhance a feeling of well-being, enjoyment and satisfaction'. Moreover, emperical studies in hospitality industry observed that customer satisfaction can be ensured by eliciting positive emotions (Lin and Liang, 2011; Kincaid et al., 2010) and provision of memorable service experiences (Hou et al., 2013). In this regard, Hosany and Witham (2010) posited that customer experience can effect their emotions and satisfaction levels and also develops a competitive advantge for service providers that is difficult to imitate.

An initial conceptualisation of customer experience was developed by Pine and Gilmore (1999) who proposed four dimensions of customer experience including education, entertainment, escapism, and esthetics. Their conceptualisation is based on the argument that customers no longer assess the functional and technical attributes of the service quality (Gentile et al., 2007); Rather, they look for affective memories to create a holistic personal experience that dazzle their senses, engage them personally, touch their hearts, and stimulate their minds, while indulging in fantasies, feelings and fun (Hosany and Witham, 2010). This concept served as base for a number of studies focusing on the understanding of consumer experiences (Gentile et al., 2007). However, with a few exceptions, research on the measurement and application of Pine and Gilmore's (1999) dimensions of customer experience remain sparse (Hosany and Witham, 2010). Contextually, Oh et al. (2007) developed a measurement scale and tested it in bed-andbreakfast industry. Later, this scale was tested by Hosany and Witham (2010) in the context of cruise holidays, however, they called for further research to validate this measurement scale in other service contexts and test its relationship with consumer consumption evaluations. Therefore, this study aims to validate Oh et al.'s (2007) measurement model in the context of resort hotels and examine the effects of four realms of customer experience on customer emotions and satisfaction levels. Specific objectives of the study include (i) to validate the experience economy scale proposed by $\mathrm{Oh}$ et al. (2007); (ii) to examine the effect of experience economy dimensions on customer emotions; and (iii) to examine how these customer emotions develop customer satisfaction.

A report published by www.ey.com titled as "Global Hospitality Insights 2014" stated that the changes in leisure travel preferences and the rise of emerging markets has resulted in bookings for resort hotels increasing at a much higher rate than the industry average. Yet, it is very surprising that, despite being one of the fastest growing tourism industries, resort hotels are often overlooked by the researchers (Ali et al., 2013). In this context, Line and Runyan (2012) reviewed 274 articles published in four top hospitality journals from 2008 to 2010 . In their review paper, they state that resort hotels are the least studied comprising only $0.7 \%$ of the total industry studied. However, the presence of research targeting this industry in top hospitality journals suggests its relevance to the field (Ali et al., 2013). Therefore, this study is conducted in the context of resort hotels.

The remainder of this paper is organized as follows. The first section consists of the theoretical background and concepts that are central to the study followed by the conceptual model and discusses the relationships among model elements. The next section narrates the research methodology and data collection. The last part consists of the findings, implications, and suggestion for future research directions.

\section{Conceptual Background of the Study}

\section{Experience Economy}

Experience economy is used as an overarching concept for service providers in leisure and 
recreation industry whose primary goal is providing high quality experiences (Heintzman, 2012; Mehmetoglu and Engen, 2011). The concept of experiences were introduced by Holbrook and Hirschman (1982, p. 132) who stated that, 'experiences trigger a steady flow of fantasies, feelings, and fun'. Pine and Gilmore (1999) further explored the concept of experiences by coining the term, 'experience economy', which is the final phase of economic progression that has developed from commodity, product and service economy. Experience economy is the final stage where the service providers focus on staging unforgettable satisfactory experiences (Wong, 2013; Olsson et al., 2012) by adding value to their offerings in order to be successful (Berry et al., 2002). In this context, Pine and Gilmore (1999, p. 12) defined experience as 'events that engage individuals in a personal way'; whereas Oh, Fiore and Jeong (2007, p. 120) define experiences as, 'enjoyable, engaging, memorable encounters for those consuming these events'.

While discussing experience economy, Pine and Gilmore (1998) identified four realms of customer experiences including entertainment, education, esthetic and escapism. These four dimensions are differentiated across two axes i.e., the degree of customer involvement and the connection of customer with the surroundings (Hosany and Witham, 2010). Customer involvement can either be active referring that customer is consuming and producing the service i.e., rafting, rock climbing etc., or it can be passive referring that customer is not physically involved and rather mentally involved in the experience i.e., theatre, museum etc., (Bharwani and Jauhari, 2013; Mehmetoglu and Engen, 2011). With regards to the connection of customer with surroundings, it is divided into two points, i.e., absorption or immersion. Absorption suggests that the customer has a certain distance to the stage or the experience (e.g., watching a movie) while immersion indicates that the customer gets 'drawn in' the experience; as shown in Figure 1.

In tourism and leisure industry, most of the offerings are related to the tourists' experience of visiting, observing, watching, enjoying, learning and living different life modes (Smith et al., 2013; Walls et al., 2011; Stamboulis and Skayannis, 2003). Consequently, everything that a tourist gets is a perception, emotional or behavioural experience offered by the tourism and leisure service providers (Oh et al., 2007). Additionally, Sternberg (1997, p. 954) posits that 'tourists are tourist because they want to compensate for their secular, disenchanted mundane lives through a temporary exposure to the other-to the adventurous, foreign, ancient, or spectacular. Tourism establishments make it their business to shape, package and sell such experiences'. Therefore, the challenge for the marketers is to grasp the distinctive characteristics of tourists (Perdue, 2002) and provide them with experiences that are unique, emotionally charged, and of high personal value (Hosany and Witham, 2010).

Various researchers have studied the tourist experience from many perspectives, however, Pine and Gilomre's (1999) four dimensions of experience including entertainment, education, esthetic and escapism has attained much more

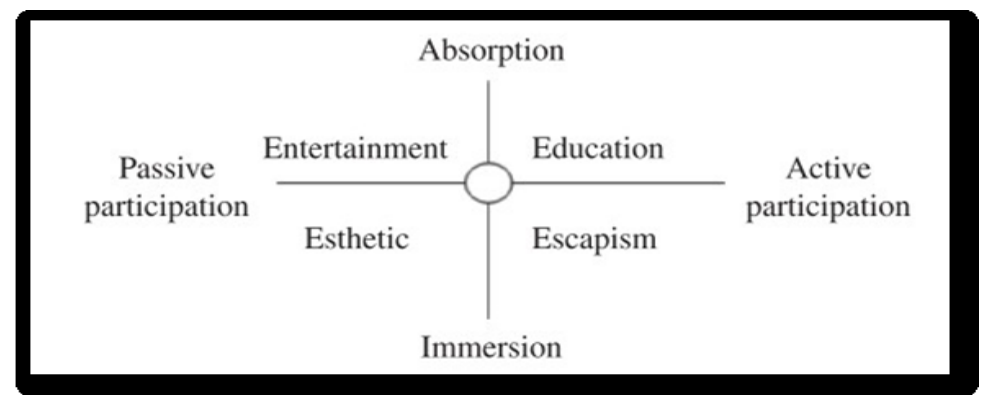

Figure 1. Dimensions of Experience (adapted from Pine and Gilmore, 1999, p. 30) 
prominence and attention (Mehmetoglu and Engen, 2011). The first dimension is entertainment which is developed when passive absorption is observed by the customer such as watching a theatre performance (Oh et al., 2007). It is one of the oldest forms of experiences and transpires when participants observe performances and activities of others (Hosany and Witham, 2010). The second dimension is esthetic where the customer has a passive participation and immersion in the experience. Examples for esthetic dimensions include a beautiful arrangement of historical relics in a museum, an attractive servicescape or ambience in a resort hotel or experiencing the breath-taking scenery of Niagara Falls (Mehmetoglu and Engen, 2011). For esthetic experiences, according to Oh et al., (2007) participants are expected to enjoy the experience without changing the environment presented to them. The third dimension is education which refers to an experience where the participant actively participates but is in absorption such as snorkelling, scuba diving or ski-schools. Pine and Gilmore (1999) state that in educational experiences, participants are expected to increase their skills or knowledge. Oh et al. (2007) provides an example of a Living History Farm where parents and children go together and attend demonstrations of historical farm skills, such as rope making, spinning, weaving, wood carving, and chair caning etc. The fourth and the last dimension is escapism which happens when the participant is affecting the actual performances in the real or virtual environment for example, by rafting or playing in a casino (Hosany and Witham, 2010). According to Oh et al. (2007), participants who engage in escapism experience usually want to take a break from their everyday routine and escape for a while. To summarise, it can be stated that entertainment experience is about feeling, the educational experience learning, the esthetic experience presence, and the escapist experience doing influence customers' emotions and satisfaction levels (Mehmetoglu and Engen, 2011; Hosany and Witham, 2010; Oh et al., 2007). Many scholars in service marketing have applied experience economy to investigate the multi-layered system of consumer experience (Hosany and Witham, 2010; Mehmetoglu and Engen, 2011).
Considering that resort hotel is an experienceoriented industry sector, experience economy concept is a logical choice in the assessment of consumer behaviour while visiting resort hotels.

\section{Emotions}

Customer emotion has been studied as a central element by the researchers while investigating perceptions of service experiences (Lin and Liang, 2011). For example, Bagozzi et al. (1999, p. 184) define emotion as 'a mental state of readiness that arises from cognitive appraisals of events or thoughts; has a phenomenological tone; is accompanied by physiological processes; is often expressed physically; and may result in specific actions to affirm or cope with the emotion, depending on its nature and the person having it'. Similarly, Ortony, Chore and Collins (1987) state that emotion is an internal mental state. Considering these definitions, Farber and Hall (2007) discusses three characteristics of emotions. Emotions are considered as internal mental state and this notion is supported by many researchers (Petzer and Meyer, 2012; Teller and Dennis, 2012; Svari et al., 2011; Palmer, 2010; Jang and Namkung, 2009; Bagozzi et al., 1999; Mehrabian and Rusell, 1979). Secondly, emotions are not cognitive state, rather are affective states of subjective feelings (Rose et al., 2012; Jang et al., 2011; Jang and Namkung, 2009). The last characteristic of emotions is that they are incited due to some stimuli and episodic in nature (Plutchik, 2003). In this context, Burns and Neisner (2006) emotions are considered to be a person's positive (pleased, relaxed, etc.) and negative (nervous, annoyed, etc.) feelings. This study also adopts the definition of emotions as the affective responses triggered by customer's experience.

The emotional responses elicited during the experiences are described either by expressions, such as joy, anger, sadness, guilt, and fear, or by emotional categories, such as pleasantness/unpleasantness, elaxation/action, or calmness excitement (Russell, 1979). Studies by Bitner (1992), Ladhari (2009) and Pareigis et al.(2011) also support the notion that various facets of customer experience develops customers' emotional responses. 
Similarly, Jani and Han (2011) conducted a research in hospitality industry and observed that customer emotions are strongly influenced by the service-encounter performance. This discussion thus concludes that customer experiences may influence the emotional states of the customers. It is therefore, hypothesised as:

Hypothesis 1: Educational experience has a positive and significant influence on emotions.

Hypothesis 2: Entertainment experience has a positive and significant influence on emotions.

Hypothesis 3: Esthetic experience has a positive and significant influence on emotions.

Hypothesis 4: Escapism experience has a positive and significant influence on emotions.

\section{Customer Satisfaction}

Service providers in every industry strive for customer satisfaction because of its impact on their performance and profits (Ali and Amin, 2014; Ryu et al., 2012; Jani and Han, 2011; Nadiri and Hussain, 2005). Because of its benefits and impacts on service providers, numerous researchers have studied its conceptualisation and measurement (Wong and Dioko, 2013; Slatten et al., 2011). It is mostly conceptualised as the difference of customers' expectations and service providers' performance (Ryu et al., 2012). Oliver (1997, p. 13) defines customer satisfaction as 'a judgment that a product, or service feature, or the product or service itself, provides a pleasurable level of consumption-related fulfilment, including levels of under or over fulfilment'. Another conceptualisation is presented by Day (1984, p. 497) who considers satisfaction as a cognition and defines it as 'a post-choice evaluative judgment concerning a specific purchase selection'. Also customer satisfaction is considering it as an emotional response (Jani and Han, 2011; Han and Back, 2007). For instance, Westbrook and Oliver (1991) posit that satisfaction is a post-choice evaluative judgment concerning a specific purchase selection using four emotions-laden items to study customer satisfaction. Oliver (1997, p. 319) also supports this notion and states that 'emotion coexists alongside various cognitive judgments in producing satisfaction'. This study also considers customer satisfaction as a central element to understanding customer consumption experiences.
In terms of its determinants, many researchers have observed the significance of emotions on customer satisfaction (Clemes et al., 2011; Jang and Namkung, 2009; Ladhari, 2009; Martin et al., 2008; Oliver, 1997; Mano and Oliver, 1993; Westbrook and Oliver, 1991; Westbrook, 1987). Lin and Liang (2011) investigated the extent to which emotions influence customer satisfaction and behavioural intentions. They stated that emotions affect customer satisfaction and behavioural intentions positively. Han and Back (2007) investigated the influence of positive and negative emotions on customer satisfaction and found the same results. The results are also supported by other researchers (Ali and Amin, 2014; Lin and Mattila, 2010; Lee et al., 2009; Jang and Namkung, 2009; Ladhari, 2009; Martin et al., 2008; Burns and Neisner, 2006). This discussion thus concludes that emotions may influence the satisfaction of the customers. It is therefore, hypothesised:

Hypothesis 5: Emotion has a positive and significant influence on customer satisfaction.

\section{Research Methodology}

The target population for this study was limited to those guests who had stayed at resort hotels in Malaysia for at least once. The survey was conducted through face-to-face interaction with the guests at two tourist spots of Malaysia i.e., Langkawi and Penang. Resorts in Malaysia are competitive and establishes greater competitive advantages in Langkawi and Penang during September - November 2013. A selfadministered survey was used to collect the using non-probability convenience sampling technique. Data collection was conducted by distributing questionnaires to guests at different times of the day, over three weeks period. Guests were explained with the purpose of the research. A total of 600 questionnaires were distributed and after deletion of incomplete responses, 450 questionnaires were deemed complete to use further showing a response rate of $75 \%$ from the original target sample population. This sample size is consistent with sample size requirements for SEM (e.g.., minimum of 10 respondents for each item in the survey instrument (Chin, 1998a). This sample size also fulfils the condition of necessary sample size of 231 respondents 
Table 1. Demographic Profile of the Respondents ( $n=450)$

\begin{tabular}{lll}
\hline Demographic Characteristic & Percentage \\
\hline Gender & Male & $58 \%$ \\
\multirow{3}{*}{ Age } & Female & $42 \%$ \\
& Less than 20 Years & $3 \%$ \\
& $21-30$ Years & $20 \%$ \\
\multirow{4}{*}{ Education Level } & $31-40$ Years & $37 \%$ \\
& Above 40 Years & $30 \%$ \\
& Bachelor Degree & $53 \%$ \\
& Master Degree & $39 \%$ \\
\hline
\end{tabular}

Table 2. Descriptive Statistics and Reliability Analysis

\begin{tabular}{llcl}
\hline & No. of Items & $\begin{array}{c}\text { Mean } \\
\text { Score }\end{array}$ & $\begin{array}{l}\text { Cronbach's } \\
\text { Alpha }\end{array}$ \\
\hline Educational Experience & 4 & 3.62 & 0.889 \\
Entertainment Experience & 4 & 3.93 & 0.841 \\
Esthetic Experience & 4 & 3.74 & 0.731 \\
Escapist Experience & 4 & 3.99 & 0.880 \\
Emotions & 4 & 3.92 & 0.808 \\
Customer Satisfaction & 4 & 3.81 & 0.757 \\
\hline
\end{tabular}

considering the $99 \%$ confidence level, standard deviation of 0.5 and $+/-1 \%$ margin of error (Bulpitt, 1987). Out of these 450 respondents, $58 \%$ were male whereas $42 \%$ were female. About $3 \%$ were between $16-20$ years of age, $50 \%$ were between 21 and 30 years, $17 \%$ were between the ages of $31-40$ years and $30 \%$ were older than 41 years. About $53 \%$ of the total respondents had bachelor degree whereas $37 \%$ had a master degree. Demographic profile of the respondents is shown in Table 1.

The constructs in this study were measured using a five-point Likert-type scale with multiple items. All measurement items validated in previous studies were borrowed and were adapted to match with the aim of this present study. The questionnaire was based on 24items in total. Dimensions of experience were measured using 4-items each adapted from Hosany and Witham (2010) and Oh et al. (2007), who studied the four dimensions (Educational Experience, Entertainment Experience, Esthetic Experience \& Escapist Experience) in hospitality industry and find them valid to apply further. Emotions were operationalised also using 4-items adapted from Lin and Liang (2011) whereas customer satisfaction was operationalised also using the 30 4-items (emotion-laden) proposed by Westbrook and Oliver (1991). All the items were required to be rated on a 5-point Likert scale, ranging from 1 (strongly disagree) to 5 (strongly agree). The questionnaire was sent to one (1) hospitality practitioner and two (2) hospitality academics to check the face and content validity. Based on their suggestions, a few modifications were made in the structure of questions.

Since a multi-item scale was used to measure each of the construct, an inter-item analysis is used to verify these scales for internal consistency or reliability (Nunnally and Bernstein, 1994). Specifically, Cronbach alpha was calculated for each scale. All scales were deemed reliable as they surpass the minimum threshold of 0.70 for Cronbach alpha values (Nunnally, 1978) as shown in Table 2.

Table 2 also shows the descriptive statistics related tp dimensions of customer experiences, emotions and customer satisfaction. Ratings on 'educational experience' (mean=3.62), 'entertainment experience' (mean=3.93), 'esthetic experience' (mean=3.74), 'escapist experience' (mean=3.99), 'emotions' (mean=3.92), and 'customer satisfaction' 
Ali F., K. Hussain and R. Omar (2016) / European Journal of Tourism Research 12, pp. 25-40

(mean=3.81) represents that respondents' agreed to the questions asked.

\section{Findings}

For this study, hypotheses were tested based on structural equation modelling using a Partial Least Squares (PLS) method. In order to conduct the analysis, Smart PLS M3 Version 2.0 (Ringle et al., 2005) software was used. Bootstrapping technique was applied to determine the significance levels of the loadings, weights, and path coefficients.
Following the procedure suggested by Anderson and Gerbing (1988), validity and goodness of fit of measurement model was estimated before testing the structural relationships outlined in the structural model.

\section{Measurement Model}

First, the measurement model was tested for convergent validity. This was assessed through factor loadings, composite reliability (CR) and average variance extracted (AVE) (Hair et al., 2006). Table 3 shows that all item loadings

Table 3. Validity and Reliability for Constructs

\begin{tabular}{|c|c|c|c|c|}
\hline \multicolumn{2}{|c|}{ Measurement Items } & Loadings & $\mathbf{C R}^{\mathrm{a}}$ & $\mathrm{AVE}^{\mathrm{b}}$ \\
\hline \multicolumn{5}{|c|}{ Education Experience } \\
\hline Ed1 & The experience has made me more knowledgeable & 0.882 & 0.924 & 0.753 \\
\hline Ed2 & I learned a lot during my experience & 0.883 & & \\
\hline Ed3 & It stimulated my curiosity to learn new things & 0.874 & & \\
\hline Ed4 & It was a real learning experience & 0.831 & & \\
\hline \multicolumn{5}{|c|}{ Entertainment Experience } \\
\hline En1 & Activities at the resort were amusing to watch and perform & 0.795 & 0.899 & 0.689 \\
\hline En2 & Activities at the resort were captivating to watch and perform & 0.858 & & \\
\hline En3 & Activities at the resort were entertaining to watch and perform & 0.862 & & \\
\hline & Activities at the resort were fun to watch and perform & 0.803 & & \\
\hline \multicolumn{5}{|c|}{ Esthetics Experience } \\
\hline Es1 & I felt a real sense of harmony & 0.848 & 0.917 & 0.735 \\
\hline Es2 & Just being here was very pleasant & 0.881 & & \\
\hline Es3 & The setting was very attractive & 0.870 & & \\
\hline Es4 & The setting really showed attention to design detail & 0.830 & & \\
\hline \multicolumn{5}{|c|}{ Escapism Experience } \\
\hline Ec1 & I felt I played a different character here & 0.875 & 0.941 & 0.800 \\
\hline Ec2 & I felt like I was living in a different time or place & 0.908 & & \\
\hline Ec3 & The experience here let me imagine being someone else & 0.892 & & \\
\hline Ec4 & I totally forgot about my daily routine & 0.903 & & \\
\hline \multicolumn{5}{|c|}{ Emotions } \\
\hline E1 & I have felt peaceful during my stay at this resort hotel & 0.825 & 0.873 & 0.632 \\
\hline E2 & I have felt happy during my stay at this resort hotel & 0.797 & & \\
\hline E3 & I have felt relaxed during my stay at this resort hotel & 0.832 & & \\
\hline E4 & I have felt relieved during my stay at this resort hotel & 0.722 & & \\
\hline \multicolumn{5}{|c|}{ Customer Satisfaction } \\
\hline CS1 & I am satisfied with my decision to stay in this resort. & 0.764 & 0.846 & 0.579 \\
\hline CS2 & My choice to stay in this resort was a wise one. & 0.790 & & \\
\hline CS3 & I think I did the right thing when I chose to stay in this resort. & 0.767 & & \\
\hline CS4 & I feel that my experience with this resort has been enjoyable & 0.722 & & \\
\hline \multicolumn{5}{|c|}{$\begin{array}{l}\text { a Composite reliability = (square of the summation of the factor loadings) / [(square of the summation of the fac } \\
\text { loadings) }+ \text { (square of the summation of the error variances)] }\end{array}$} \\
\hline
\end{tabular}


exceeded the recommended value of 0.6 (Chin, 1998). Composite reliability values, which depict the degree to which the construct indicators indicate the latent construct, exceeded the recommended value of 0.7 (Hair et al., 2006) while average variance extracted, which reflects the overall amount of variance in the indicators accounted for by the latent construct, exceeded the recommended value of 0.5 (Hair et al., 2006).

The next step was to assess the discriminant validity, which refers to 'the extent to which the measures are not a reflection of some other variables' and it is indicated by the low correlations between the measure of interest and the measures of other constructs (Ramayah et al., 2013; p. 142). Table 4 shows that the square root of the AVE (diagonal values) of each construct is larger than its corresponding correlation coefficients pointing towards adequate discriminant validity (Fornell and Larcker, 1981). To conclude, the measurement model showed an adequate convergent validity and discriminant validity.

\section{Structural Model}

SmartPLS 2.0 was used to test the structural model and hypotheses (Ringle et al., 2005). A bootstrapping procedure with 2000 iterations was performed to examine the statistical significance of the weights of sub-constructs and the path coefficients (Chin et al., 2008). As PLS does not generate overall goodness of fit indices, the R2 is the primary way to evaluate the explanatory power of the model (Wasko and Faraj, 2005). However another diagnostic tool is presented by Tenenhaus et al. (2005) to assess the model fit and is known as the goodness of fit (GoF) index. The GoF measure uses the geometric mean of the average communality and the average R2 (for endogenous constructs). Hoffmann and Brinbrich (2012) report the following cut-off values for assessing the results of the GoF analysis: GoFsmall $=0.1 ;$ GoFmedium $=0.25$; GoFlarge $=0.36$. For the model used in this study, a GoF value of 0.558 is calculated which indicates a very good model fit as shown in Table 5.

Following the measurement model and goodness of fit, the hypothesized relationships in the structural model were tested. Figure 2, shows the results of the analysis. The corrected $R^{2} s$ in the figure refer to the

Table 4. Discriminant Validity

$\begin{array}{llllll}1 & 2 & 3 & 4 & 5 & 6\end{array}$

\begin{tabular}{lllllll}
\hline Customer & & & & & & \\
Satisfaction & $\mathbf{0 . 7 6 1}$ & & & & & \\
Education & 0.599 & $\mathbf{0 . 8 6 7}$ & & & & \\
Emotions & 0.627 & 0.580 & $\mathbf{0 . 7 9 5}$ & & & \\
Entertainment & 0.610 & 0.773 & 0.630 & $\mathbf{0 . 8 3 0}$ & & \\
Escapism & 0.587 & 0.617 & 0.587 & 0.605 & $\mathbf{0 . 8 9 4}$ & $\mathbf{0 . 8 5 7}$ \\
Esthetics & 0.502 & 0.435 & 0.510 & 0.456 & 0.508 & \\
\hline
\end{tabular}

Table 5. Goodness of Fit Index

\begin{tabular}{|c|c|c|}
\hline & AVE & $\mathbf{R}^{2}$ \\
\hline Customer Satisfaction & 0.5795 & 0.3937 \\
\hline Education Experience & 0.7529 & \\
\hline Emotions & 0.6324 & 0.4982 \\
\hline Entertainment Experience & 0.6893 & \\
\hline Escapism Experience & 0.8003 & \\
\hline Esthetics Experience & 0.7352 & \\
\hline Average Scores & $0.6983^{a}$ & $0.4459^{6}$ \\
\hline $\mathrm{AVE}^{*} \mathrm{R}^{2}$ & 0.311 & \\
\hline$\left(G O F=\sqrt{A V E \times R^{2}}\right)$ & 0.558 & \\
\hline
\end{tabular}


explanatory power of the predictor variable(s) on the respective construct. All four dimensions of customer experience explains $49.8 \%$ per cent of their emotions $\left(R^{2}=0.498\right)$, whereas emotions of customer explains 39.4 per cent of customer satisfaction $\left(\mathrm{R}^{2}=0.394\right)$. In regard to model validity, Chin et al. (2008) classified the endogenous latent variables as substantial, moderate or weak based on the $\mathrm{R}^{2}$ values of $0.67,0.33$, or 0.19 respectively. Accordingly, both emotions $\left(R^{2}=0.498\right)$ and customer satisfaction $\left(R^{2}=0.394\right)$ can be described as moderate.

The complete results of the structural model and hypotheses testing are presented in Table 6 . The results show a strong support for all the five hypotheses of the study. $\mathrm{H} 1$ was hypothesizing that educational experience will influence customer emotions positively and significantly. The results show a strong support for this hypothesis $(\mathrm{H} 1: \mathrm{b}=0.105, \mathrm{t}=1.980$, sig $<$ 0.05). Similarly, $\mathrm{H} 2$ hypothesised that entertainment experience will influence customer emotions positively and significantly. The results show a strong support for this hypothesis $(\mathrm{H} 2: \mathrm{b}=0.320, \mathrm{t}=4.499$, $\mathrm{sig}<$ 0.01). A strong support was also found for $\mathrm{H} 3$ and $\mathrm{H} 4$ hypothesising the positive and significant effect of esthetic experience and escapist experience on customer emotions $(\mathrm{H} 3: \mathrm{b}=0.204, \mathrm{t}=4.082$, sig $<0.01 ; \mathrm{H} 4: \mathrm{b}=$ $0.225, \mathrm{t}=4.025$, sig $<0.01)$. These results are consistent with the study conducted by Hosany and Witham (2010) who observed a significant influence of dimensions of customer

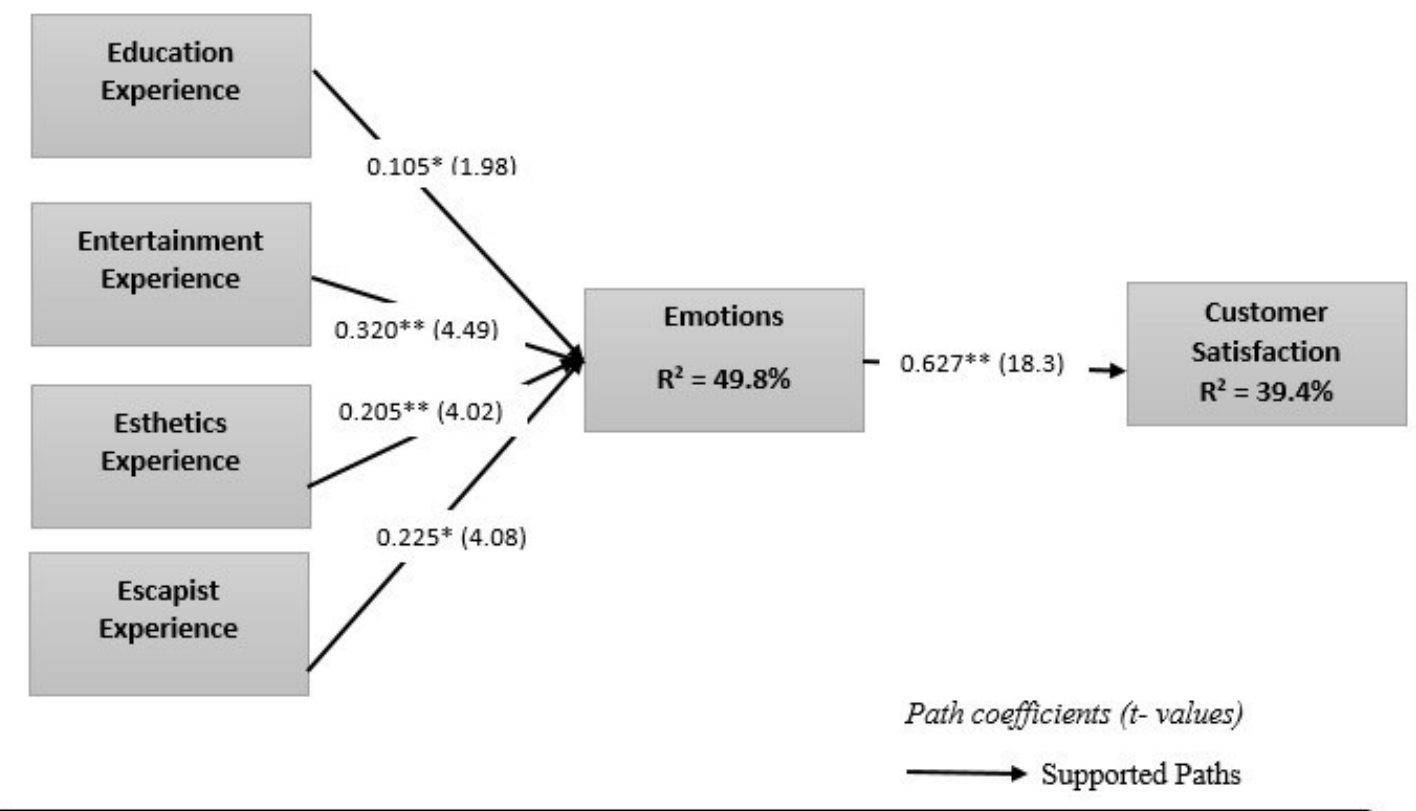

$* \mathrm{P}<0.05 ; * * \mathrm{p}<0.01$

Figure 2. Results of the Structural Model

Table 6. Structural Estimates (Hypotheses Testing)

\begin{tabular}{llllll}
\hline Hypothesis & $\begin{array}{l}\text { Standard } \\
\text { Beta }\end{array}$ & $\begin{array}{l}\text { Standard } \\
\text { Error }\end{array}$ & T Statistics & Decision \\
\hline $\mathrm{H} 1$ & Education $\rightarrow$ Emotions & 0.105 & 0.072 & $1.98^{*}$ & Supported \\
$\mathrm{H} 2$ & Entertainment $\rightarrow$ Emotions & 0.320 & 0.071 & $4.499^{* *}$ & Supported \\
$\mathrm{H} 3$ & Escapism $\rightarrow$ Emotions & 0.225 & 0.055 & $4.082^{* *}$ & Supported \\
$\mathrm{H} 4$ & Esthetics $\rightarrow$ Emotions & 0.204 & 0.051 & $4.025^{* *}$ & Supported \\
$\mathrm{H} 5$ & Emotions $\rightarrow$ Customer Satisfaction & 0.627 & 0.034 & $18.358^{* *}$ & Supported \\
\hline${ }^{*} \mathrm{P}<0.05 ;{ }^{* *} \mathrm{P}<0.01$ & & & & \\
\hline
\end{tabular}


experience over their emotions. Similarly, other researchers such as Bitner (1992), Ladhari (2009) and Pareigis et al. (2011) also supports the notion that various facets of customer experience develops customers' emotional responses. Similarly, Jani and Han (2011) conducted a research in hospitality industry and observed that customer emotions are strongly influenced by the service-encounter performance. The last hypothesis was $\mathrm{H} 5$, which hypothesises positive and significant effect of emotions on customer satisfaction. The results strongly support this hypothesis $(\mathrm{H} 5: \mathrm{b}=0.627, \mathrm{t}=18.358$, sig < 0.01). These results are consistent with the previous studies. Lin and Liang (2011) investigated the extent to which emotions influence customer satisfaction and behavioural intentions. They stated that emotions affect customer satisfaction and behavioural intentions positively and significantly. Han and Back (2007) also investigated the influence of positive and negative emotions on customer satisfaction and found the same results. The results are also supported by other researchers (Ali and Amin, 2014; Lin and Mattila, 2010; Lee et al., 2009; Jang and Namkung, 2009; Ladhari, 2009; Martin et al., 2008; Burns and Neisner, 2006).

\section{Common Method Variance}

Common method variance refers to 'variance that is attributable to the measurement method rather than to the construct of interest' (Podsakoff et al., 2003; pp. 879). It may exist due to the single survey method used to collect responses (Hair et al., 2006). This variance was addressed by following the guidelines provided by Podsakoff et al. (2003) and presented the survey items (Lindell and Whitney, 2001). At the data analysis stage of the study, Harman's (1967) one-factor test was also applied to control the common method variance. All the items of the study were entered into a principal component analysis with varimax rotation to assess if a single factor emerges from the factor analysis accounting for more than 50 percent of the co-variation. The results indicated that there was more than one factor that accounted for the majority of covariance and it does not appear to be a common method bias concern in the present study.

\section{Discussion and Managerial Implications}

Based on the concepts of experience economy presented by Pine and Gilmore (1998), Oh et al. (2007) developed a scale for measurement of tourists' experiences and tested it in bed and breakfast accommodation. Hosany and Witham (2010) tested this scale in cruise ship industry and call for further validation of the scale in other facets of hospitality contexts. They also suggested to investigate the mechanisms of how tourist experiences can elicit customer emotions. Considering this research call, this study aimed to examine the effects of four realms of customer experience on customer emotions and satisfaction levels in resort hotels. Data was collected from the guests of Malaysian resort hotels. Structural equation modelling based on partial least squares method was used to analyse the data and test the relationships between the constructs. Overall, the findings of this study enhance the understanding of experience economy concepts in resort hotels and their effect on emotions and satisfaction of customers. The study implications are discussed below and future research areas are highlighted.

Results from this study indicate that customer experiences can be classified in four dimensions including entertainment, education, esthetic and escapism. Analysis of the data proves reliability and validity of all the four dimensions of customer experience. More specifically, the findings of this study establish the viability and generalizability of Oh et al. (2007) and Hosany and Witham's (2010) measurement model in a different consumption situation. However, the difference exists in these four dimensions based on their relative importance in terms of predicting the outcome variables of emotions and customer satisfaction. In contrast to study conducted by Oh et al. (2007), the results from this study show that entertainment was the main determinant of customer emotions in Malaysian resort hotels. Entertainment was also considered the second most important determinant of outcome variables in the study conducted by Hosany and Witham (2010) on cruiser experiences. Entertainment is an integral part of a tourism. Moreover, Gee (2000, p.22) states that, 'The core principle of the resort concept is the creation of an 
environment that will promote and enhance a feeling of well-being, enjoyment and satisfaction'. In relative terms, escapism was the second most important dimension in predicting customer emotions in this study. According to Snepenger et al., (2007) and Hosany and Witham (2010), escapism remains an important motivator for vacations and personal travel. Yang and Chan (2010, p. 58) states, that 'to escape from normal life' as the main motivating factor to visit a resort hotel. The findings of this study suggest that esthetics is the third main determinants to predict customer emotions. Many researchers have discussed the influence of esthetics and physical environment on customer emotion in any service setting (Pareigis et al., 2011; Ladhari, 2009; Bitner, 1992). Similarly, Oh et al. (2007) and Hosany and Witham (2010) declare esthetics as the main determinant of experiential outcomes. A service setting's physical environment is comprised of a variety of different elements including the esthetics and ambient factors such as color, air, scent, illumination, facilities, layout (Lin and Liang, 2011; Han and Ryu, 2009; Baker et al., 1994). These factors are all interrelated and they work together (Mehrabian and Russell, 1974) to influence consumer behavior holistically, not as separate individual factors (Bitner, 1992). For example, in-store experiences developed by the physical environment also trigger customer emotions (Lin and Liang, 2011). In this context, customer's emotions are influenced by both the design and the ambient factors of physical environment that generates excitement among the customers (Harris and Ezeh, 2008). Richardson (2000) identified two characteristics of a resort hotel including sufficient indoor amenities encompassing pleasant physical environment and convenient entertainment facilities. The second key characteristic of the resort hotel is its location which is in a unique vacation spot that is desirable because of its climate, scenery, and recreational attractions. For both these two characteristics, esthetics remain an integral part (Mill, 2008). With regards to the educational dimension, while various resort hotels offers some opportunities for the guests to increase their knowledge and skills (e.g., massage techniques, cooking lessons), such experiences were of little importance in predicting customer emotions.
Findings from different studies suggest that the four dimensions of customer experience have differences in terms of their relative importance to predict different outcomes. Therefore, marketers should understand these differences as they offer practical implications for implementing segmentation and positioning strategies based on experiences of customers (Hosany and Witham, 2010).

The results also found that customer emotions are very strong predictors of customer satisfaction in resort hotels. These findings are all in line with the previous studies who observed that emotions evoked during the consumption experience influence satisfaction judgements (Ali and Amin, 2014; Pareigis et al., 2011; Hosany and Witham, 2010; Lin and Mattila, 2010; Jang and Namkung, 2009; Ladhari, 2009; Lee et al., 2009; Martin et al., 2008; Burns and Neisner, 2006; Bitner, 1992;). Oliver (1997) states that a strong theoretical support regarding the link between positive emotion and customer satisfaction is evident. While assessing a service experience, customers basically draw on their emotional state and any change in this emotional state influences their satisfaction levels (Lin and Liang, 2011). Psychology literature has demonstrated that emotions can affect evaluative processes (Mehrabian and Russell, 1974). Consumers' emotions and evaluations are observed to have a strong correlation with customer satisfaction (Burns and Neisner, 2006).

Resort hotels are becoming one of the fastest segments of tourism attractions around the world because a drastic increase has been seen in the number of people travelling to resort hotels situated in the natural exotic locations to escape from their routine life and enjoy and entertain themselves (Ali et al., 2013). The fast development in this tourism sector makes it very competitive and forces the resort hotels to develop various strategies for attracting and retaining customers by differentiating themselves from competitors (Mill, 2008). At the same times, resort hotels are facing the challenge of understanding customer experiences and the resulting post consumption evaluations. The findings from this study provide some insight on the 
customer experience dimensions and their relationship with emotions and customer satisfaction. More specifically, the study validates a measurement scale to examine resort hotels' guest's experiences along the four dimensions. This can help the management of resort hotels to develop suitable promotional and marketing campaigns. For instance, resort hotels should emphasize the educational, esthetic, escapist, and entertaining values of the stay at their resort. The pre-consumption performance (advertisements) and during-consumption service performance of the resort hotels must elicit positive emotions of the guests as these are the string predictors of customer satisfaction. In addition, resort hotels should focus on developing attractive and esthetically pleasing environments as these are significant in developing memorable experiences. This offer additional support that resort hotels in Malaysia needs to consider physical environment as an effective marketing strategy in order to appeal to customers from other Asian or Western counties. Similarly, having a good quality services would be in vain if the physical environment is not attractive and well maintained, since a bad physical environment can change customers, perception of the actual service quality levels resulting in negative behavioral intentions.

\section{Limitations and Directions for Future Research}

Despite of enhancing our understating of experience economy concept in resort hotels, this study entails some limitations. This study was only conducted in resort hotels located in two Malaysian popular tourist spots (Langkawi and Penang). Conducting a similar study on resort hotels guests' at other locations in Malaysia may provide fruitful insights and it will help this study in generalisability of the results. Owing to the sample size, the findings from this study cannot be generalized to the wider resort hotels guest population. Future research could also test the validity of the measurement scale of customer experience in other service settings such as package holidays, selfcatering villas, classic luxury hotels and wildlife adventure tourism etc. Moreover, most of the recent studies have focused on customer experience using generic dimensions, however, holistic approach to study factors of customer experience are yet to be studied empirically. Therefore, future studies emphasizing on the identification of factors of customer experience may be useful to find new dimensions of customer experience specific to different contexts. The findings of this study indicated that customer experience dimensions elicit emotions in customers. Future studies can investigate the effects of customer experience on different types of emotions such as joy, pleasure, and love. Moreover, future studies might also consider how people having different characteristics perceive service experience and its effect on their emotions and behaviours. Moreover, in terms of the antecedents of customer satisfaction, this study only considered customer experience and emotions. However, there might be other factors that can influence customer satisfaction. Hence, future studies can also incorporate other factors such as perceived price and perceived social interaction etc. Finally, this research has sought to understand the resort hotel experience dimensions using an existing measurement model. It might be interesting to develop other items for assessment of other attributes and aspects of the resort hotel experience.

\section{References}

Ali, F., Omar, R. and Amin, M. (2013). An examination of the relationships between physical environment, perceived value, image \& behavioural Intentions: A SEM approach towards Malaysian resort hotels. Journal of Hotel and Tourism Management, 27(2), 9-26.

Ali, F. and Amin, M. (2014). The influence of physical environment on emotions, customer satisfaction and behavioural intentions in Chinese resort hotel industry. Journal for Global Business Advancement, 7(3), 249-266.

Anderson, J. and Gerbing, D. (1988). Structural modeling in practice: a review and recommended two-step approach. Psychological Bulletin, 103(3), 411-423.

Bagozzi, R., Gopinath, M. and Nyer, P. (1999). The role of emotions in marketing. Academy of Marketing Science, 27(2), 184-206. 
Ali F., K. Hussain and R. Omar (2016) / European Journal of Tourism Research 12, pp. 25-40

Baker, J., Grewal, D. and Parasuraman, A. (1994). The influence of store environment on quality inferences and store image. Journal of the Academy of Marketing Science, 22(4), 328-339.

Berry, L., Carbone, L. and Haeckel, S., (2002). Managing the total customer experience. MIT Sloan Management Review, 43(3), 85-89.

Bharwani, S. and Jauhari, V. (2013). An exploratory study of competencies required to co-create memorable customer experiences in the hospitality industry. International Journal of Contemporary Hospitality Management, 25(6), 823-843.

Burns, D. and Neisner, L. (2006). Customer satisfaction in a retail setting: The contribution of emotion. International Journal of Retail and Distribution Management, 34(1), 49-66.

Chin, W.W. (1998), Issues and opinions on structural equation modelling. MIS Quarterly, 22(1), 7-16.

Chin, W.W., Peterson, R.A. and Brown, P.S. (2008). Structural equation modelling in marketing: Some practical reminders. Journal of Marketing Theory and Practice, 16(4), 287-298.

Clemes, M., Gan, C. and Ren, M. (2011). Synthesizing the effects of service quality, value, and customer satisfaction on behavioral intentions in the motel industry:

An empirical analysis", Journal of Hospitality and Tourism Research, 35(4), 530-568.

Day, R. (1984). Modelling choices among alternative responses to dissatisfaction. In NA - Advances in Consumer Research, 11, eds. Thomas C. Kinnear, Provo, UT: Association for Consumer Research, pp. 496-499.

Farber, M. E. and Hall, T. E. (2007). Emotion and environment: Visitor's extraordinary experiences along the Dalton highway in Alaska. Journal of Leisure Research, 39(2), 248-270.

Fornell, C. and Larcker, D. F. (1981). Evaluating structural equation models with unobservable variables and measurement error. Journal of Marketing Research, 18(1), 39-50.

Gee, C.Y. (2000). Resort Development and Management. Educational Institute of the
American Hotel \& Motel Association, Michigan, MI.

Geissler, G. L. and Rucks, C.T. (2011). The overall theme park experience: A visitor satisfaction tracking study. Journal of Vacation Marketing, 17(2), 127-138 .

Gentile, C., Spiller, N. and Noci, G. (2007). How to sustain the customer experience: An overview of experience components that co-create value with the customer. European Management Journal, 25(5), 395-410.

Hair, J.F., Black, W.C., Babin, B.J., Anderson, R.E. and Tatham, R.L. (2006). Multivariate Data Analysis (6 $6^{\text {th }}$ ed.). Upper Saddle River, NJ: Prentice-Hall.

Han, H. and Ryu, K. (2009). The roles of the physical environment, price perception, and customer satisfaction in determining customer loyalty in the family restaurant industry. Journal of Hospitality and Tourism Research, 33(4), 487-510.

Han, H. and Back, K.J. (2007). Investigating the effects of consumption emotions on customer satisfaction and repeat visit intentions in the lodging industry. Journal of Hospitality Marketing \& Management, 15(3), 5-30.

Harman, H.H. (1967). Modern Factor Analysis. University of Chicago Press, Chicago, IL.

Harris, L. and Ezeh, C. (2008) Servicescape and loyalty intentions: An empirical investigation. European Journal of Marketing, 42(3), 390-422.

Heintzman, P. (2012). The spiritual dimension of campers' park experience: management implications. Managing Leisure, 17(4), 291-310.

Hoffmann, A. and Birnbrich, C. (2012). The impact of fraud prevention on bankcustomer relationships: An empirical investigation in retail banking. International Journal of Bank Marketing, 30(5), 390407.

Holbrook, M. and Hirschman, E. (1982). The experiential aspects of consumption: Consumer fantasies, feelings, and fun. Journal of Consumer Research, 9(2), 132140.

Hosany, S. and Gilbert, D. (2009). Measuring tourists' emotional experiences toward hedonic holiday destinations. Journal of Travel Research, 49(4), 513-526. 
Hosany, S., \& Witham, M., (2010). Dimensions of cruisers' experiences, satisfaction, and intention to recommend. Journal of Travel Research, 49(3), 351-364.

Hou, M., Wu, X. and Hu, Z. (2013). Personnel service, consumption emotion, and patronage intention in department stores. International Business Research, 6(3), 621.

Jang, S. and Namkung, Y., (2009). Perceived quality, emotions, and behavioral intentions: Application of an extended Mehrabian-Russell model to restaurants. Journal of Business Research, 62(4), 451460.

Jang, S., Liu, Y. and Namkung, Y. (2011). Effects of authentic atmospherics in ethnic restaurants: investigating Chinese restaurants. International Journal of Contemporary Hospitality Management, 23(5), 662-680.

Jani, D. and Han, H., (2011). Investigating the key factors affecting behavioral intentions: Evidence from a full-service restaurant setting. International Journal of Contemporary Hospitality Management, 23(7), 1000-1018.

Kincaid, C., Baloglu, S., Mao, Z. and Busser, J. (2010). What really brings them back? The impact of tangible quality on affect and intention for casual dining restaurant patrons. International Journal of Contemporary Hospitality Management, 22(2), 209-220.

Ladhari, R. (2009). Service quality, emotional satisfaction, and behavioural intentions: A study in the hotel industry. Managing Service Quality, 19(3), 308-331.

Lee, Y., Back, K. and Kim, J. (2009). Family restaurant brand personality and its impact on customer's emotion, satisfaction, and brand loyalty. Journal of Hospitality and Tourism Research, 33(3), 305-329.

Lin, I. Y. and Mattila, A. S. (2010). Restaurant servicescape, service encounter, and perceived congruency on customers' emotions and satisfaction. Journal of Hospitality Marketing \& Management, 19(8), 819-841.

Lin, J. and Liang, H. (2011). The influence of service environments on customer emotion and service outcomes. Managing Service Quality, 21(4), 350-372.
Lindell, M. K. and Whitney, D.J. (2001). Accounting for common method variance in cross-sectional research designs. Journal of Applied Psychology, 86(1), 114-121.

Line, N. D. and Runyan, R.C., (2012). Hospitality marketing research: Recent trends and future directions. International Journal of Hospitality Management, 31(2), 477-488.

Mano, H. and Oliver, R. (1993). Assessing the dimensionality and structure of the consumption experience: Evaluation, feeling, and satisfaction. Journal of Consumer Research, 20(3), 451-466.

Martin, D., O'Neill, M., Hubbard, S. and Palmer, A. (2008). The role of emotion in explaining consumer satisfaction and future behavioural intentions. Journal of Services Marketing, 22(3), 224-236.

Mehmetoglu, M. and Engen, M. (2011). Pine and Gilmore's concept of experience economy and its dimensions: An empirical examination in tourism. Journal of Quality Assurance in Hospitality \& Tourism, 12(4), 237-255.

Mehrabian, A. and Russell, J. (1974). An Approach to Environmental Psychology. The MIT Publisher, England.

Mill, R.C. (2008). Resort Management and Operation. ( $2^{\text {nd }}$ Ed.), John Willey \& Sons, Inc. New York.

Miller, A.R. and Grazer, W.F. (2002). The North American cruise market and Australian tourism. Journal of Vacation Marketing, 8(3), 221-234.

Nadiri, H. and Husain, K., (2005). Perceptions of service quality in North Cyprus hotels. International Journal of Contemporary Hospitality Management, 17(6), 469-480.

Nunnally, J. (1978). Psychometric Theory. (2 ${ }^{\text {nd }}$ ed.) McGraw-Hill, New York, NY.

Nunnally, J.C. and Bernstein, I.H. (1994). Psychometric Theory. ( $3^{\text {rd }}$ ed.). McGrawHill Inc., New York, NY.

Oh, H., Fiore, A.M. and Jeong, M. (2007). Measuring experience economy concepts: tourism applications. Journal of Travel Research, 46(2), 119-131.

Oliver, R.L. (1997). Satisfaction: A Behavioral Perspective on the Consumer. McGrawHill, New York, NY. 
Olsson, L., Friman, M., Pareigis, J. and Edvardsson, B. (2012). Measuring service experience: Applying the satisfaction with travel scale in public transport. Journal of Retailing and Consumer Services, 19(4), 413-418.

Ortony, A., Chore, G. R. and Collins, A. (1988). The Cognitive Structure of Emotions. Cambridge University Press, England.

Palmer, A. (2010). Customer experience management: A critical review of an emerging idea. Journal of Services Marketing, 24(3), 196-208.

Pareigis, J., Edvardsson, B. and Enquist, B. (2011). Exploring the role of the service environment in forming customer's service experience. International Journal of Quality and Service Sciences, 3(1), 110124.

Perdue, R. (2002). Perishability, yield management, and cross-product elasticity: A case study of deep discount season passes in the Colorado Ski industry. Journal of Travel Research, 41(1), 15-22.

Petzer, D.J. and Meyer, C.F.D. (2012). Service receivers' negative emotions in airline and hospital service settings. Journal of Services Marketing, 26(7), 484-496.

Pine, J. and Gilmore, J. (1999). The Experience Economy. Harvard Business School Press, Boston.

Plutchik, R. (2003). Emotions and Life: Perspectives from Psychology, Biology, and Evolution. United Book Press, Baltimore, MD.

Podsakoff, P. M., MacKenzie, S.B., Lee, J.Y. and Podsakoff, N.P. (2003). Common method biases in behavioral research: $A$ critical review of the literature and recommended remedies. Journal of Applied Psychology, 88(5), 879-903.

Ramayah, T., Yeap, J.A.L. and Igatius, J. (2013). An empirical inquiry on knowledge sharing among academicians in higher learning institutions. Minerva, 51(2), 131154.

Richardson, E.C. (2000). Resort Management. In Brymer, R.M. (eds.). in hospitality and tourism: An introduction to the industry $\left(9^{\text {th }}\right.$ ed.), John Wiley \& Sons, Inc. New York, NY, pp. 374-379.

Ringle, C.M., Wende, S. and Will, A. (2005). SmartPLS 2.0 (beta). Available at: http://www.smartpls.de (accessed 11 November 2013).

Rose, S., Clark, M., Samouel, P. and Hair, N. (2012). Online customer experience in eretailing: An empirical model of antecedents and outcomes. Journal of Retailing, 88(2), 308-322.

Ruiz, D., Castro, B. and Diaz, I. (2012). Creating customer value through servicee: An empirical study in the hotel. Tourism and Hospitality Management, 18(1), 37-53.

Russell, J.A. (1979). Affective space is bipolar. Journal of Personality and Social Psychology, 37(4), 345-356.

Ryu, K., Lee, H. and Kim, W. (2012). The influence of the quality of the physical environment, food, and service on restaurant image, customer perceived value, customer satisfaction, and behavioral intentions. International Journal of Contemporary Hospitality Management, 24(2), 200-223.

Schmitt, B. (1999). Experiential marketing. Journal of Marketing Management, 15(1), 53-67.

Slatten, T., Krogh, C. and Connolley, S. (2011). Make it memorable: Customer experiences in winter amusement parks. International Journal of Culture, Tourism and Hospitality Research, 5(1), 80-91.

Smith, J.W., Moore, R.L. and Sommerville, M. (2013). Non-sovereign visitor satisfaction: a case study of military training on the Appalachian Trail. Managing Leisure, 18(3), 239-251.

Snepenger, D., King, J., Marshall, E. and Uysal, M., (2007). Modelling Iso-Ahola's motivation theory in the tourism context. Journal of Travel Research, 45(2), 127139.

Stamboulis, Y. and Skayannis, P. (2003). Innovation strategies and technology for experience-based tourism", Tourism Management, 24(1), 35-43.

Sternberg, E. (1997). The iconography of the tourism experience. Annals of Tourism Research, 24(4), 951-969.

Svari, S., Slåtten, T., Svensson, G. and Edvardsson, B. (2011). A SOS construct of negative emotions in customers' service experience (CSE) and service recovery by firms (SRF). Journal of Services Marketing, 25(5), 323-335. 
Teixeira, J., Patrício, L., Nunes, N.J., Nóbrega, L., Fisk, R.P. and Constantine, L. (2012). Customer experience modeling: from customer experience to service design. Journal of Service Management, 23(3), 362-376.

Teller, C. and Dennis, C. (2012). The effect of ambient scent on consumers' perception, emotions and behaviour: A critical review. Journal of Marketing Management, 28(12), 14-36.

Tenenhaus, M., Vinzi, V., Chatelin, Y.M. and Lauro, C. (2005). PLS path modelling. Computational Statistics and Data Analysis, 48(1), 159-205.

Walls, A., Okumus, F., Wang, Y. and Kwun, D. J. W. (2011). Understanding the consumer experience: An exploratory study of luxury hotels. Journal of Hospitality Marketing \& Management, 20(2), 166-197.

Wasko, M.M and Faraj, S. (2000). It is what one does: why people participate and help others in electronic communities of practice. The Journal of Strategic Information Systems, 9(2-3), 155-173.

Westbrook, R. and Oliver, R. (1991). The dimensionality of consumption emotion patterns and consumer satisfaction. Journal of Consumer Research, 18(1), 8491.
Westbrook, R.A. (1987). Product/consumptionbased affective responses and postpurchase processes. Journal of Marketing Research, 24(3), 258-270.

Wong, I. (2013). Exploring customer equity and the role of service experience in the casino ervice encounter. International Journal of Hospitality Management, 31(1), 91-101.

Wong, I.A. and Dioko, A. N. (2013). Understanding the mediated moderating role of customer expectations in the customer satisfaction model: The case of casinos. Tourism Management, 36(3), 188-199.

Wu, C. H.J. and Liang, R.D. (2009). Effect of experiential value on customer satisfaction with service encounters in luxury hotels. International Journal of Hospitality Management, 28(4), 586-593.

http://www.ey.com/Publication/vwLUAssets/EY Global_hospitality_insights_2014/\$FILE/ $\bar{E} Y$-Global-hospitality-insights-2014.pdf (Accessed $1^{\text {st }}$ March 2014)

Yang, Y. and Chan, A. (2010). A hierarchical approach to measure service performance in the resort hotel's service encounters. Journal of Tourism, Hospitality \& Culinary Arts, 2(1), 57-66. 